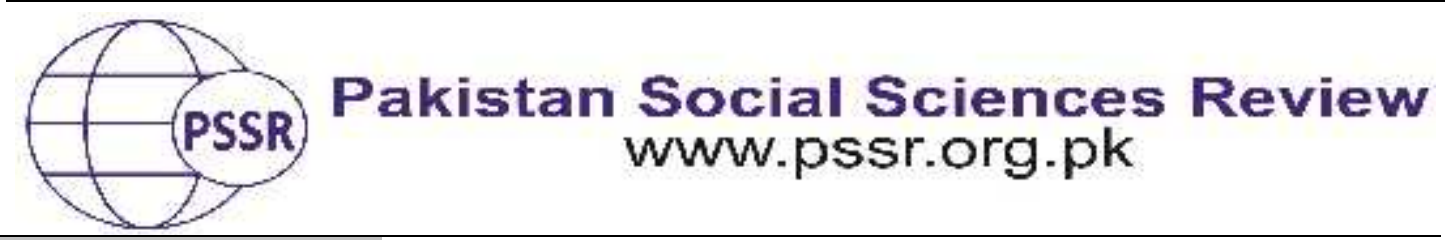

RESEARCH PAPER

\title{
Teaching English through Critical Pedagogy (CP): Challenges and Coping Strategies in Pakistani EFL Classrooms
}

\author{
Sarwat Anjum ${ }^{1}$ Dr. Habibullah Pathan* 2 Waqar Ali Shah ${ }^{3}$
}

1. MS Scholar, English Language Development Centre, Mehran University of Engineering \& Technology, Jamshoro, Sindh, Pakistan

2. Director, English Language Development Centre, Mehran University of Engineering \& Technology, Jamshoro, Sindh, Pakistan

3. Lecturer, English Language Development Centre, Mehran University of Engineering \& Technology, Jamshoro, Sindh, Pakistan

\begin{tabular}{|c|c|}
\hline INFO & ABSTRACT \\
\hline Rece & dagogy is a \\
\hline 021 & learners to think critically on social is \\
\hline & existing knowledge by mean of questi \\
\hline & teachers in Pakistan \\
\hline & $\mathrm{ms}$ to \\
\hline & \\
\hline $\mathrm{Cr}$ & \\
\hline $\operatorname{lagog}$ & ualitative \\
\hline cal Thinking & $\begin{array}{l}\text { ever, } \\
\text { nded }\end{array}$ \\
\hline & hod \\
\hline FL), & vere \\
\hline & stan. \\
\hline & d by \\
\hline $\begin{array}{l}{ }^{*} \text { Corresponding } \\
\text { Author }\end{array}$ & $\begin{array}{l}\text { es in } \\
\text { n. A }\end{array}$ \\
\hline & er from both universities was \\
\hline
\end{tabular}

\section{Introduction}

Critical pedagogy, abbreviated as $\mathrm{CP}$ is a teaching approach which enables the learners to think critically (Kalssom\&Malick, 2020). The concept of CP was initially given by Paul Freire, a Brazilian pedagogue and educationalist. According to Freire (2004) a critical pedagogue teaches the learners critically by allowing them to think critically; the class is learner-centered where learners have full right to question the knowledge of teacher. Besides, there is another approach of teaching which Freire (2004) termed it as 'Banking Mode'. This is the traditional approach where the EFL classrooms are teacher-centered; Teacher is the only source of 
knowledge, and he does not allow any learner to question his knowledge (Kalssom \& Malick, 2020).

Teachers can achieve $\mathrm{CP}$ in their classroom by focusing on dialogue in class (Mazdaee \& Maftoon , 2012). By dialogue, Freire meant that teachers should teach interactively. For instance, teaching and learning takes place in an interactive way, where both the teacher and learners exchange their roles and share their authority. Thus, it develops a mutual relationship between teacher and learner. Freire termed it as the Fluid relationship (Soozandehfar \& Noroozisiam, 2011). Akbari (2007) claims that implementation of $\mathrm{CP}$ in an EFL classroom brings up the problem-solving approach which enables the learners to practice their critical ability thinking. However, the scenario in EFL classrooms in Pakistan is different. In Pakistan, EFL teachers usually shoe reluctancy to implement $\mathrm{CP}$ in their classrooms. Focusing on this gap in research and practices, the present study aims to investigate EFL teachers' perspectives regarding implementation of CP in public sector universities in Sindh Pakistan.

\section{ELT in Pakistan}

English language teaching is an important phenomenon in the context of Pakistan. It serves as the medium of instruction in academics of Pakistan; and it is the official language of Pakistan. The people in Pakistan believe English is the language of power and prosperity. Therefore, it has been believed that a person who is fluent in English communication, may get better job opportunities in Pakistan and all over the world. Thus, everybody desires to learn and use English.Despite of being so important and wanted, the teaching of English in Pakistan is just not up to the mark. Rehman (2003) described the main characteristics ELT in educational system of Pakistan: (a) teacher-centered; learning without life experiences; uncontextualized; already prescribed syllabus outline, focus on rote learning; exam and results driven; learning without critical thinking. Freire (2004) named this approach 'Banking Model' model' where teacher is the only authority and he is the only source of knowledge which teacher imparts into the brains of learners and learners absorb the knowledge without applying critical thinking on it (Kalsoom \&Malick, 2020).

\section{World View on Critical Pedagogy}

$\mathrm{CP}$ is the philosophy of teaching and learning where teachers are responsible to make learners think critically. Implementation of $\mathrm{CP}$ develops in learners the critical consciousness and makes them problem-solvers (Lynch, 2020). Therefore, the learners get opportunity to think critically on all issues related to their surroundings. Jamil (2014) mentions the two major principles of Freirean critical pedagogy:

1. To make the learners' critical thinkers by developing in them the critical thinking ability. 
2. To empower the learners so that they can question the existing knowledge to seek the truths.

Therefore, the principles of $\mathrm{CP}$ can be easily achieved by the teachers by bringing eight features of Freirean pedagogy in their teaching style: (1) 'Questioning' is the effective practice to be followed by the teacher; (2) 'Change at personal level' is the need of an hour. Teaching through banking model would only leads to the absorption of fixed concepts. However, according to Freire (2001) an ideal teacher is the one who can facilitate his learners to learn and adapt at personal level; (3) 'Dialogue' is the most significant concept in Freirean pedagogy. It mainly focuses on the student-teacher interaction to share a mutual or fluid relationship (Mazdaee \& Maftoon , 2012); (4) 'Problem-solving approach' where learners are exposed to their real-life experiences. They consider their every problem as a challenge and solve it through critical thinking ability; (5) 'Codification', also called as 'picture imaging real situation'. In this method, teacher students through images related to their real-life experiences or social issues. Learners will observe the images and share their ideas based on their knowledge and experience; (6) 'Culture circle', commonly known as group discussion; (7) 'Culture of Silence' is the situation where the oppressor has power over the oppressed. Likewise, in English learning situation speakers with better fluency are considered more powerful than those with poor speaking skills. This results in the loosing self-confident in learners; (8) 'Praxis' is described as the action-reflection-action. Learners can learn from his actions by reflecting on his own experience (Jamil, 2014).

\section{CP in EFL Classroom}

English language has been taught traditionally through the banking model (Freire, 2004). The banking-model is commonly known as the teacher-centered approach where teacher is the authority, and he is the only knowledge source in classroom. Teacher in the traditional method never allows his learners to question their knowledge. Learner in banking-model of teaching, never get a chance to think critically or interact to share his ideas (Kalsoom \& Malick, 2020); Freire (2005) rejects this method of teaching and introduced the method of critical pedagogy in which learner gets opportunity to learn through critical thinking approach; Critical pedagogy in English language teaching develops in learners the critical consciousness and enable them to challenge existing knowledge by sharing their critical ideas on it (Asakereh \& Weisi, 2018).

\section{Implementation of $\mathrm{CP}$ in an EFL Classroom in Pakistan}

In the field of education English has achieved the prominent status in Pakistan; IELTS, TOEFL and many other high stakes testing requires best fluency and accuracy in English language. Therefore, there are number of institutions and private academies to teach and prepare the learners for learning and using English. Thus, everyone in Pakistan no matter of which family background they belong, wan their children to get admission in an English medium school (Manan. et. al, 2015). 
However, the teaching scenario in Pakistani language class classroom is different. EFL teachers teach English through traditional method (Kalsoom \& Malick, 2020). There are number of institutes where the teaching of English language is carried out through critical pedagogy. But still a huge number of EFL teachers are still reluctant to implement critical pedagogy in their classroom due to some unavoidable issues.

\section{Material and Methods}

\section{Research Design}

The research design adopted for the present study was mixed-method approach. Riazi (2014) defined the mixed-method approach as the combination of qualitative and quantitative approach which is used to get the insights of participants on research questions from both the perspectives. Therefore, the mixedmethod approach has been used by the researcher to collect the rich data to answer the research questions of the present study.

\section{Data Collection Tools}

The process of data collection is beneficial to examine the research problem in its real setting (Yin, 2009). The data collection for the present study was collected through semi-structured interviews and the close-ended questionnaire.

\section{Semi-structured Interviews}

The qualitative data for the present study was collected by mean of semistructured interviews. Semi-structured interviews are defined as a type of interview which is made by the combination of close and open-ended questionnaires; each question in semi-structured interviews has further one or two questions with 'why' or 'how' based on the responses of the interviewee Adams, 2015). Adams (2015) claims that semi-structured interviews are best suited for the data collection of mixed method approach, as it always brings fresh and rich insights via in-depth inquiry. Therefore, for the present study, an interview protocol (see Appendix B) was designed by the researcher and piloted. After piloting the interviews, the interview protocol was updated with slight changes.

\section{Close-ended Questionnaire}

The questionnaire for the quantitative data collection was an adapted version ofMahmoodarabi \& Khodabakhsh's (2015) research entitled as "EFL Teachers' Beliefs about Critical Language Pedagogy". The research was initially done in the context of Iran. However, the questionnaire then adapted by the researcher with changes as per required for the context of Pakistan. There was total 17 items in the close-ended questionnaire. The reliability of the present questionnaire was measured by the Cronbach Alpha value. The Cronbach value for the piloted questionnaire was .86 . 


\section{Sampling}

Purposive sampling has been implemented by the researcher to select the participants of the present study. Cresswell\& Clark (2011) defined the purposive sampling as the method of selecting the research participants for the data collection procedure; purposive sample provides you the participants who are best at their field of study and provides in-depth information. The selected participants for the present study were the EFL teachers of two public universities. For the semistructured interviews, five EFL teachers (M.Phil. and Ph.D. qualified) were selected from, each university $(n=10)$. However, for the close-ended questionnaire, all the available staff was selected to fill the close-ended questionnaire.

The names of the two selected public universities of Sindh Pakistan are mentioned below:

1. IELL department, University of Sindh, Jamshoro.

2. ELDC department, Mehran University of Engineering and Technology, Jamshoro.

\section{Data Analysis}

The qualitative data gathered through semi-structured interviews was analyzed by the thematic analysis. Galanis (2018) claims that thematic analysis is the effective method of analysis for the data that has been collected via any king of interviews. In this method, there are different stages through which the collected data must pass till the final themes generate. The present study follows the model of thematic analysis introduced by Braun and Clerk (2006). All the semi-structured interviews were conducted and recorded as per the consent of research participants. The recorded interviews then transcribed by the researcher and then they passed through six main stages of thematic analysis presented by Braun and Clerk (2006). The EFL teachers' responses were coded as T (T1-T10).

Unlike the qualitative data, quantitative data was collected through the closeended questionnaire that was first adapted in the MS Word. It was then converted into online Google forms. The data collected through the online Google forms was analyzed automatically and displayed into pie charts with averages and mean.

\section{Findings} categories:

The findings of the present research study have been divided into two 


\section{Findings Interviews}

The findings from semi-structured interviews were categorized into two main themes: Problems faced by EFL teachers in implementation CP and strategies to deal with the problems faced by EFL teachers in implementation of CP. Each of the main themes includes ten more sub themes (one for each problem or strategy).

\section{Problems faced by EFL teachers in implementation CP}

Based on the findings, there are ten common problems due to which EFL teachers fail to implement $\mathrm{CP}$ in their classroom successfully:

1. Background: Leaners coming from different background is the issue. When learners come from different diversities, they bring with themselves different abilities. This difference in abilities can pose up issue to the EFL teacher in imputation of $\mathrm{CP}$ in their class classroom.

2. Language barrier: Most of the students in EFL classroom are not proficient in English language. Therefore, the language barrier in students make them reluctant to share their ideas in any dialogue activity.

3. Time: Critical pedagogy is a time taking approach and its activities requires a lot of time for the successful outcome. However, the time that EFL teachers are allotted with is not enough. Therefore, due to inadequate time, they fail to implement CP in their EFL classroom.

4. Syllabus bound: It was found that syllabus is yet another issue for the EFL teachers at both universities. The syllabus is already prescribed due to which EFL teachers' focus remain the completion of course before examination rather bringing material that enable them to think critically.

5. Learners' interest: In the present context, students are habitual with traditional methodology. Most of them do not even find it comfortable to take part in any interactive activity. They remain the passive learners in EFL classroom.

6. Learners' expectation: Most of the students are not the independent learners. They still rely on teacher to impart the knowledge into their minds.

7. Teachers' unwillingness: critical pedagogy requires teachers to share their authority with their learners. By doing so, learners will come out of the state of oppression. However, the findings on this are different. EFL Teachers are not ready to share their authority rather they find themselves the kings of knowledge. 
8. Class size: large classroom is yet another big issue in EFL classrooms here. Each class has 100 to 150 students. This huge number of students make it impossible for the teacher to implement CP successfully.

9. Offensive and hurting ideas: Teachers at both universities believe that when they allow students to share their ideas, sometimes their ideas turn out to be offensive or hurting against the feelings of other learners.

10. Teachers' comfort in Traditional approach: EFL teachers at both universities are fond of traditional methodology. Most of them still do not want to come out of their comfort zone and try the critical approach in their EFL classroom.

Strategies to deal with the problems faced by EFL teachers in implementation of CP

Based on the findings, there are ten strategies which an EFL teacher may follow to implement $\mathrm{CP}$ in their classroom successfully:

1. Teaching basic rules of grammar: Teachers should teach their students the basic rules of grammar and design activities to practice those rules. In this way all the students will develop language proficiency and will easily share their ideas without any barrier in language.

2. Need-based teaching: EFL teachers at both universities need to teach the students according to their need. They need to bring the topics related to their life and career in class and initiate the dialogical activities in class.

3. Learning through life experience: EFL teachers can combine their teaching material with their daily life activities. In this way learners will take great interest and learn in class with participation.

4. Reduced class size: EFL teachers can reduce the number of students in each class and make the class small size. With this, every learner will get equal chance to participate and share their thinking in class.

5. Empowering learners: EFL teachers can share their authority to empower their learners. When learners will get equal authority to think critically and share ideas with teacher, they will learn in a better way.

6. Sufficient time: Teachers can design their lesson plan and class activity that will go smoothly in sufficient time.

7. Group discussions: Group discussions encourage learners of all ability to participate and in class and get opportunity to share their ideas. 
8. Socio-political awareness: Teachers can introduce their learners with social and political issue as to aware them. So, they can critically think on them and share their critical ideas.

9. Need based teaching material: EFL teacher can design his teaching material according to the need of the learner.

10. Interactive activities: Interactive activities can be the better tool to engage learners in practicing their critical ability and make them active participants in class.

\section{Findings from Close-ended Questionnaire}

\begin{tabular}{|c|c|c|c|c|c|c|c|c|c|c|c|}
\hline \multirow[t]{2}{*}{ S.no } & \multirow[t]{2}{*}{ Statements } & \multicolumn{5}{|c|}{ Responses from U1 } & \multicolumn{5}{|c|}{ Responses from U2 } \\
\hline & & S.A & A & $\mathrm{P}$ & $\mathrm{D}$ & S.D & S.A & $\mathrm{A}$ & $\mathrm{P}$ & $\mathrm{D}$ & S.D \\
\hline 01 & $\begin{array}{l}\text { It's an EFL teacher who } \\
\text { makes their learners critical } \\
\text { thinkers. }\end{array}$ & $76 \%$ & $12 \%$ & $08 \%$ & $04 \%$ & $00 \%$ & $62.5 \%$ & $20.8 \%$ & $12.5 \%$ & $4.2 \%$ & $00 \%$ \\
\hline 02 & $\begin{array}{l}\text { EFL teacher enables learners } \\
\text { to share their world realities. }\end{array}$ & $52 \%$ & $16 \%$ & $24 \%$ & $08 \%$ & $00 \%$ & $56 \%$ & $16 \%$ & $28 \%$ & $00 \%$ & $00 \%$ \\
\hline 03 & $\begin{array}{l}\text { EFL teacher should design } \\
\text { for learners need-based } \\
\text { syllabus. }\end{array}$ & $60 \%$ & $16 \%$ & $24 \%$ & $00 \%$ & $00 \%$ & $44 \%$ & $32 \%$ & $24 \%$ & $00 \%$ & $00 \%$ \\
\hline 04 & $\begin{array}{l}\text { EFL teacher should share his } \\
\text { authority with learners. }\end{array}$ & $20 \%$ & $28 \%$ & $48 \%$ & $04 \%$ & $00 \%$ & $40 \%$ & $20 \%$ & $40 \%$ & $00 \%$ & $00 \%$ \\
\hline 05 & $\begin{array}{l}\text { EFL teacher should design } \\
\text { for learner's material related } \\
\text { to life. }\end{array}$ & $56 \%$ & $32 \%$ & $12 \%$ & $00 \%$ & $00 \%$ & $44 \%$ & $28 \%$ & $24 \%$ & $04 \%$ & $00 \%$ \\
\hline 06 & $\begin{array}{l}\text { EFL teacher should involve } \\
\text { learners in dialogical } \\
\text { activities. }\end{array}$ & $64 \%$ & $28 \%$ & $08 \%$ & $00 \%$ & $00 \%$ & $76 \%$ & $12 \%$ & $12 \%$ & $00 \%$ & $00 \%$ \\
\hline 07 & $\begin{array}{l}\text { Knowledge only lies in the } \\
\text { heads of teacher. }\end{array}$ & $44 \%$ & $40 \%$ & $08 \%$ & $08 \%$ & $00 \%$ & $36 \%$ & $40 \%$ & $20 \%$ & $04 \%$ & $00 \%$ \\
\hline 08 & $\begin{array}{l}\text { EFL teacher should enable } \\
\text { learners to make themselves } \\
\text { their learning opportunities. }\end{array}$ & $48 \%$ & $36 \%$ & $16 \%$ & $00 \%$ & $00 \%$ & $68 \%$ & $24 \%$ & $08 \%$ & $00 \%$ & $00 \%$ \\
\hline 09 & $\begin{array}{l}\text { EFL teacher should carry out } \\
\text { open communication for } \\
\text { ideas sharing by learners. }\end{array}$ & $52 \%$ & $20 \%$ & $28 \%$ & $00 \%$ & $00 \%$ & $64 \%$ & $20 \%$ & $16 \%$ & $00 \%$ & $00 \%$ \\
\hline 10 & $\begin{array}{l}\text { EFL course books in Pakistan } \\
\text { are related to learners' real- } \\
\text { life. }\end{array}$ & $36 \%$ & $32 \%$ & $28 \%$ & $04 \%$ & $00 \%$ & $48 \%$ & $36 \%$ & $16 \%$ & $00 \%$ & $00 \%$ \\
\hline 11 & $\begin{array}{l}\text { EFL teacher should have } \\
\text { dialogical approach based on } \\
\text { real life issues. }\end{array}$ & $44 \%$ & $28 \%$ & $28 \%$ & $00 \%$ & $00 \%$ & $48 \%$ & $36 \%$ & $16 \%$ & $00 \%$ & $00 \%$ \\
\hline 12 & $\begin{array}{l}\text { EFL teachers should design } \\
\text { the EFL material by } \\
\text { following critical approach. }\end{array}$ & $52 \%$ & $16 \%$ & $32 \%$ & $00 \%$ & $00 \%$ & $52 \%$ & $40 \%$ & $04 \%$ & $04 \%$ & $00 \%$ \\
\hline 13 & $\begin{array}{l}\text { EFL teachers should enhance } \\
\text { in learners the critical } \\
\text { thinking ability. }\end{array}$ & $48 \%$ & $28 \%$ & $24 \%$ & $00 \%$ & $00 \%$ & $52 \%$ & $28 \%$ & $20 \%$ & $00 \%$ & $00 \%$ \\
\hline 14 & $\begin{array}{l}\text { The EFL classroom should } \\
\text { follow the topics related to } \\
\text { sociopolitical issues. }\end{array}$ & $28 \%$ & $20 \%$ & $44 \%$ & $08 \%$ & $00 \%$ & $44 \%$ & $36 \%$ & $12 \%$ & $08 \%$ & $00 \%$ \\
\hline 15 & $\begin{array}{l}\text { EFL teachers should } \\
\text { encourage learners to value } \\
\text { their educational and social } \\
\text { system. }\end{array}$ & $48 \%$ & $28 \%$ & $20 \%$ & $04 \%$ & $00 \%$ & $24 \%$ & $52 \%$ & $20 \%$ & $04 \%$ & $00 \%$ \\
\hline 16 & $\begin{array}{l}\text { EFL teacher should aware } \\
\text { learners regarding social } \\
\text { disparities. }\end{array}$ & $78 \%$ & $08 \%$ & $06 \%$ & $00 \%$ & $00 \%$ & $36 \%$ & $40 \%$ & $12 \%$ & $12 \%$ & $00 \%$ \\
\hline 17 & $\begin{array}{l}\text { EFL teacher should allow } \\
\text { leaners to choose their own }\end{array}$ & $56 \%$ & $20 \%$ & $24 \%$ & $00 \%$ & $00 \%$ & $52 \%$ & $36 \%$ & $12 \%$ & $00 \%$ & $00 \%$ \\
\hline
\end{tabular}




\section{Discussions}

topic of discussion.

The present study was based on the three research questions. I will be discussing here the findings according to the research questions:

1. What are the challenges faced by EFL teachers in teaching English through Critical Pedagogy (CP) in EFL classroom at public sector universities in Pakistan?

It has been found that the EFL teachers face several problems while implementing CP in their classroom. Some of the issues are unavoidable such as 'Fixed syllabi. This issue is unavoidable. Teacher must follow the syllabus as per the policy of the university. Then the next important issue was 'Large class'. Large class is the reality of almost all the classrooms of Pakistan. In large class teachers find it difficult to manage the classrooms, from its sitting arrangement to its discipline. Large class is really a challenge for the EFL teachers who aim to Implement CP in their classroom. 'Traditional methodology' is another resistance for the teachers and learners. Learners are not interested in $\mathrm{CP}$ and teachers are also not willing to implement $\mathrm{CP}$ only because of their comfort at traditional methodology.

2. What are the coping strategies to be used by EFL teachers to overcome these challenges?

Despite facing number of issues in EFL classroom, EFL teacher can implement CP successfully by following some of the strategies illustrated by the EFL teachers in findings. Therefore, the most effective ones are 'Teaching through real life experiences' where learners not imparted with tones of books to cram but get chance to think critically and share their ideas. 'Interactive activities' like group discussion and teacher-learner dialogue develops in learns the critical thinking abilities.

3. What are the differences of EFL teacher's perceptions about teaching English through Critical Pedagogy (CP) in EFL classroom at public sector universities in Pakistan?

EFL teachers at both universities prefer to implement CP in their classroom. Their responses in the questionnaire show that encourage learners to question them and pose a problem-solving situation to their learners. Most of the teachers agreed to make their classrooms dialogical with issues related to the society and real life. EFL teaches at both the universities believe that they must enable learners to create learning opportunities for themselves by thinking critically the issues around the world. However, only a few EFL teachers at both universities were reluctant to implement $\mathrm{CP}$ due to their own priority to teacher-centered approach. 


\section{Conclusion}

English language plays an important role in Pakistan. It is the language or education and offices. However, the teaching of English is taken for granted in almost all the educational systems in Pakistan. The reason lies in the implementation of Banking model in teaching rather than Critical approach. $\mathrm{CP}$ is the learnercentered approach which enables learners to think critically on social realities and enable them to challenge their existing knowledge by questioning. Despite of the issues that EFL teacher face in implementation of $\mathrm{CP}$ in their classroom, there are number of strategies that EFL teacher may apply to teach English successfully through $\mathrm{CP}$.

\section{Recommendations}

ELT is the most important phenomenon in the context of Pakistan. Therefore, it needs to be taught with the critical approach. To implement the CP EFL teachers

ELT is the most important phenomenon in the context of Pakistan. Therefore, it needs to be taught with the critical approach. To implement the CP EFL teachers should create a learning environment in which learners can share his ideas and learn the things in his own way. Besides, teachers should not only teach through the fixed outline that they are prescribed with, but they also rather create their own teaching material that serves the need and the interest of the students. Moreover, A dialoguebased classroom is the need of an hour. Therefore, EFL teachers should encourage their learners to have dialogue on different topics related to the world around. 


\section{References}

Adams, W. (2015). Conducting Semi-Structured Interviews. In: Wholey, J.S., Harty, H.P. and Newcomer, K.E., Eds., Handbook of Practical Program Evaluation, Jossey-Bass, San Francisco, 492-505.https://doi.org/10.1002/9781119171386.ch19

Akbari, Ramin. (2007). Transforming lives: Introducing critical pedagogy into ELT classrooms. Elt Journal. 62. 276-283. 10.1093/elt/ccn025.

A. Mehdi Riazi and Christopher N. Candlin (2014). Mixed-methods research in language teaching and learning: Opportunities, issues, and challenges. Language Teaching, 47, pp 135-173 doi:10.1017/S0261444813000505

Asakereh, Ahmad \&Weisi, Hiwa. (2018). Raising critical consciousness in teaching reading skills using critical pedagogy principles: A case of an Iranian school graduate. Journal for Critical Education Policy Studies. 3. 60-70.

Braun, V., \& Clarke, V. (2006). Using thematic analysis in psychology. Qualitative Research in Psychology, 3, 77-101. doi:10.1191/ 1478088706qp063oa

Braun, V., \& Clarke, V. (2013). Successful qualitative research: A practical guide for beginners. London, England: SAGE.

Creswell, J.W. and Plano Clark, V.L. (2011) Designing and Conducting Mixed Methods Research. 2nd Edition, Sage Publications, Los Angeles.

Freire, P. (2001). Pedagogy of the oppressed (30th ed.). New York: Continental.

Freire, P. (2004). Pedagogy of indignation. Boulder, CO: Paradigm Publishers.

Jamil, S. (2014).Critical English Language Learning for Pakistani Graduate Students: Challenges and Possibilities, Ph.D. National University of Modern Languages, Islamabad.

Kalsoom, S., Kalsoom, N., Mallick, R. J. (2020). From banking model to critical pedagogy: Challenges and constraints in the university classrooms. UMT Education Review, 3(1), 25-44.

Lynch, Shrehan\& Ovens, Alan. (2020). Critical Pedagogy in Physical Education. in:

Peters, M. (ed.) Encyclopedia of Teacher Education Springer.

Mahmoodarabi, M. \&Khodabakhs, M. R. (2015). Critical pedagogy: EFL teachers' views, experience and academic degrees. Islamic Azad University, Sanandaj, Iran. English Language Teaching, 8(6), 100-110. doi:10.5539/elt.v8n6p100 
Manan, Syed \& David, Maya \& Francisco. (2015). English Language Teaching in Pakistan: Language Policies, Delusions and Solutions. 10.1007/978-3-319-224640_10.

Mansoor, S. (2005). Language Planning In Higher Education: A Case Study of Pakistan. Oxford University Press, USA.

Mazdaee, Mahtab \&Maftoon, Parviz. (2012). Implementing the principles of critical pedagogy in an EFL writing class. Modern Journal of

Language TeachingMethods (MJLTM)ISSN: 2251-6204

McLaren, P. (2002). Critical pedagogy: A look at the major concepts. In Antonia Darder (Eds.) The critical pedagogy reader, New York and London: Routlege/Falmer.

McLaren, P. (2007). Life in schools: an introduction to critical pedagogy in the foundations of education (5th. edn.). Boston, MA: Allyn \& Bacon.

Monchinski, Tony. (2008). Critical Pedagogy and The Everyday Classroom.Springer Netherlands 10.1007/978-1-4020-8463-8_4.

Noroozisiam, Elmira \& Mohammad, Seyyed\&Soozandehfar, Seyyed Mohammad Ali. (2011). Teaching English through Critical Pedagogy: Problems and Attitudes. Theory and Practice in Language Studies. 1. 10.4304/tpls.1.9.1240-1244.

Nowell, Lorelli \& Norris, Jill \& White, Deborah \& Moules, Nancy. (2017). Thematic Analysis: Striving to Meet the Trustworthiness Criteria. International Journal of Qualitative. 16. 10.1177/1609406917733847.

Nunan, D.(2001). Syllabus Design. In Marianne Celce-Murcia (ed,). Teaching English as a foreign Language. (3rd Edition). New York: Cengag.

O'Donoghue, T. (2007). Planning Your Qualitative Research Project: An Introduction to Interpretivist Research in Education. London and New York: Routledge.

Ohio Department of Education, (2006). Academic Content Standards: K-12 Social Studies. Columbus, $\mathrm{OH}$, Author

Perveen, A. (2015). Critical Pedagogy in a Pakistani Literature Classroom International Journal of Critical Pedagogy. 6.University of North Carolina Greensboro

Raddawi, R. \& Troudi, S. (2012). Three Elements of Critical Pedagogy in ELT. Achieving excellence through life skills education, 73-82. Proceedings of the 18th International TESOL Arabia Conference Dubai: TESOL Arabia Publications. 
Raddawi, R. \&Troudi, Salah. (2018). Critical pedagogy in EFL teacher education in the United Arab Emirates: Possibilities and challenges.TESOL International Journal. 13. 7999.

Rahman, T., 2003. Language policy, multilingualism, and language vitality in Pakistan.http://www.sil.org/asia/ldc/parallel_papers/tariq_rahman.pdf

Rajesh. R.V (2014). A study on the effectiveness of critical pedagogical approach in social studies at secondary level. University of Mysore. Department of education regional institute of education (National Council of Educational Research and Training) MYSORE - 570006.

Sarroub, Loukia \& Quadros, Sabrina. (2015). Critical Pedagogy in Classroom Discourse.New York \& Abingdon: Routledge

Sharma, Balkishan. (2016). A focus on reliability in developmental research through Cronbach's Alpha among medical, dental and paramedical professionals. Asian Pacific Journal of Health Sciences. 3. 271-278. 10.21276/apjhs.2016.3.4.43.

Soto, Carlos. (2019). Critical Pedagogy and Ethnic Minority Students in Hong Kong: Possibilities for Empowerment.Ethnicity and Inequality in the Multilingual Asian Context, p. 197-214. Singapore: Springer.

Stevenson, R. B. (2008). A critical pedagogy of place and the critical place (s) of pedagogy. Environmental Education Research, 14(3), 353-360.

Taherdoost, Hamed. (2016). Validity and Reliability of the Research Instrument; How to Test the Validation of a Questionnaire/Survey in a Research. International Journal of Academic Research in Management. 5. 28-36. $10.2139 /$ ssrn.3205040.

Troudi, S. \& Alwan, F. (2010).Teachers' feelings during curriculum change in the United Arab Emirates: Opening Pandora's Box.Teacher Development 14(1), 107-121

Yin, R. (2009). Case Study Research: Design and Methods (fourth edition). London and Singapore: Sage 